\title{
Relevance of Exchange Rates on the Trade Imbalance in the Eurozone*
}

\author{
MYOUNG SHIK CHOI*
}

\begin{abstract}
European monetary integration is causing economic imbalances because the optimal currency area criterion is not being properly met. Euro countries are experiencing chronic current account deficits. The purpose of this study is to explore the long-running divergent dynamics of real exchange rates and their determinants and influence.

In this estimation, we find that the real effective exchange rate (REER) has a long term equilibrium relation to the balance of current account, the demographic aging effect, and the stage of development effect as a Euro-zone group. Also, we find that individual REER discrepancies have greatly diminished in recent years while the misalignments of individual and group REERs show a steady converging tendency of their equilibrium rates. The co-movement effect on the REER misalignment indicates a weak influence of determinant factors. In addition, the Euro-zone drives the undervalued rate of $3.44 \%$ with the current account deficit of $0.08 \%$ for the sample period, and the REER misalignment is not closely related to the trade deficit.

The results for the future of the Eurozone would imply that the misalignments of currency cooperation members show an increasingly converging tendency of their equilibrium over time, and they also display co-integration regarding the current account balance and development phase as well as population aging.
\end{abstract}

Keywords: Co-Integration, Current Account Deficit, Demographic Aging, Euro-Zone, Filters, Exchange Rate Misalignment, Productivity, Real Effective rate

* This work was supported by the National Research Foundation of Korea Grant funded by the Korean Government(NRF-2013S1A5B5A07048288).

${ }^{* *}$ Researcher, DanKook University, Yongin-si, Gyeonggi-do, South Korea; E-mail: msc50355@gmail.com; DOI: 10.16934/isr.15.2.201412.111 


\section{INTRODUCTION}

A currency adjustment process in the course of macroeconomic behavior provides assistance to analyzing the current situation in the Euro area. For each country, Euro misalignments can have serious consequences. A poor choice of a conversion rate for European currencies and an overvalued Euro could lead to imbalances and economic slowdown. Current accounts are more divergent across EU members in spite of a convergence of interest rates. This is different from an expectation of convergence of imbalances at the introduction of the Euro monetary union.

Southern and peripheral states have run a large number of deficits due to overvalued currency misalignments as shown by Coudert et al. (2013), Couharde and Mazier (2001), Alberola and Navia (2008) and others. But estimating an equilibrium exchange rate to avoid divergent rates is complicated by the structural change experience at the transition phase as Maeso-Fernandez et al. (2006) claims, and by the larger inflation differentials as Honohan and Lane (1999) argue. Rusek (2012) finds that Germany is $20-25 \%$ undervalued, suggesting that the equilibrium rate is about $\$ 1.60$ per Euro while Greece is about 30\% overvalued, implying an equilibrium rate of $\$ 1.0$ per euro.

The real exchange rates (RERs) also display persistent deviations from price equality in currency unions. RERs have a close relationship with Eurozoneinternal relative prices, and RER adjustment is superior within the Euro area according to Berka et al. (2012). Berka and Devereux (2013) finds that RERs are overvalued by about $15 \%$ in Greece and Portugal, and 6\% in Italy and Spain. Otherwise, Cavallo et al. (2012) claims that RERs are equal to one within currency unions despite their deviations from the law of one price outside of currency unions.

Firstly, many recent studies have analyzed the consequences of RERs' deviations on the current account imbalance. Secondly, population aging causes unambiguous results in RERs, which lead to either a rise of RERs, as in Aloy and Gente (2009) or to a decline, as in Ross et al. (2009). Thirdly, several papers have examined the longer-run consequences of aging for the current account imbalance. The life cycle model of Modigliani (1970), Weil (1997), and Lee and Mason (2011) explain the responses of economics to demographic change. The dependency hypothesis of Coale and Hoover (1958) suggests that population aging decreases the current account while Bosworth et al. (2004) indicates that rapid aging appreciates the domestic currency so as to decrease the current account deficit. And Debelle and Faruqee (1996) find that the aging of advanced countries has more effect on the current account.

In summary, if exchange rate misalignments diverge between the Euro members, then these problems would be the consequences of different economic 
conditions. I believe that the potential contribution to exchange rate misalignments could be substantial but it is not clear enough to be positioned in the theoretical debate. This article reviews the long-running divergent dynamics of real exchange rates and their determinants and influence in the Euro area. We would like to develop an optimum model in the longer-term, and then subject it to an empirical test.

\section{CONCEPTUAL FRAMEWORK}

The inception of the Euro promotes more transactions in the Eurozone. It transfers the shocks of foreign exchange rate from consumers to producers. The real exchange rate is then adjusted across countries. In this section, we attempt to advance an aging exchange rate model that will explain an increasing current account imbalance among the Euro economies. We identify key implications for currency misalignment for an individual nation, and discuss the cross-border integration dimensions of demographic alteration to an external imbalance.

The optimal currency area conditions include labor mobility, price flexibility, inflation convergence, diversification of economic structure, similar openness, and other factors. In this sense, policy makers and market participants would be more interested in the real effective exchange rate (REER) when computing a currency's overall misalignment to understand the dynamic process of adjusting a country's external balance. An effective exchange rate may be a better indicator than bilateral exchange rate. A nominal effective exchange rate (NEER) is an index of the weighted average of bilateral rate between the home economy and each of the trading partners. The REER is an average of the real bilateral exchange rate. A trade-weighted REER is a popular pointer.

Exchange rates are basically determined by fundamentals. Assessing the equilibrium level of exchange rates is a great help to policy guidelines for foreign exchange market intervention since they have a major influence on prices. A number of approaches for estimating equilibrium exchange rates have been developed despite of the lack of formal standard models. The traditional approaches can be divided into three methodologies.

The first approach on purchasing power parity (PPP) is the REER, which adjusts the NEER of Hirsch and Higgins (1970). The long-run PPP approach has expanded into the multilateral NEER and the supply-sided REER. The REERs are the NEERs adjusted by relative consumer prices with the manufacturing tradeweighting of Turner and Van't dack (1993) according to Klau and Fung (2006). The second is the macroeconomic balance approach on achieving internal and external balance, with an origin in the work of Nurkse (1945). There is also fundamental equilibrium exchange rate of Williamson (1994), the desired equilibrium exchange rate, the natural real exchange rate, and the permanent equilibrium 
exchange rate. The third approach includes assessments based on estimated exchange rate equations. Equilibrium exchange rates are determined by the regression results on exchange rates structural models.

Additionally, the Balassa-Samuelson effect accounts for many of the REER variations across countries. Other large REER adjustments may be explained by transportation costs, and tariffs. And Bayoumi et al. (2006) calculates the REER indexes in the manner of aggregate traded-weights on all trades in commodities, manufactures, and services. Besides, estimating the REER can be biased because of sticky prices in the short run. Clark and MacDonald (1998) present the behavioral equilibrium exchange rate (BEER), and the short run BEER is used by MacDonald (2000), among others. Also, Lane and Shambaugh (2010) create financially-weighted effective exchange rate indices (FEER) via either the valuation channel in the short run or the trade channel in the long run by exchange rates according to Gourinchas and Rey (2007). Capital asset-based FEER is found to be qualitatively similar to PPP-based REER.

The REER is the weighted average of bilateral real exchange rates with trading partners of a country that depend further on price/cost deflator, coverage, trade weights, etc. Any deviations of the REER would indicate a fundamental misalignment to create pressures on the currency exchange. An imperfect REER signals the overvaluation of exchange rates.

The REER deviation can be expressed as $\frac{\mathrm{R}-\mathrm{R}^{*}}{\mathrm{R} *}$ where $\mathrm{R}$ is the long run PPP-based REER index and $R^{*}$ is the REER index at the base year. The current account will deteriorate as the REER deviation (home currency) is overvalued. In currency unions with the introduction of the Euro, the external imbalance of a member state has been adjusted, subject to its own constraint like debt, by the price and income process as well as the impacts of fiscal policy and ECB policy.

In the case of positive inflation differentials within the Eurozone, the national inflation differential can be expressed as $\pi-\pi^{\text {euro }}$ where $\pi$ is each national inflation rate and $\pi^{\text {euro }}$ is the Eurozone inflation rate. The deviation will increase (home currency undervalued) as $\pi-\pi^{\text {euro }}<0$ while the deviation will decrease as $\pi-\pi^{\text {euro }}$ $>0$.

In the capital market, we surmise that capital inflows into the home as $\mathrm{i}>$ $i^{\text {euro }}$ causing the expected Euro rate to rise while capital outflows as as $i<i^{\text {euro }}$, according to the international Fisher effect of $\mathrm{s}^{\wedge \text { euro }}=\mathrm{i}-\mathrm{i}^{\text {euro }}$ where $\mathrm{s}^{\wedge \text { euro }}$ is the rate of Euro exchange rate change, $i$ is the home interest rate, and $i^{\text {euro }}$ is the average interest rate of the Euro. On the other hand, the real rate will decrease and thus national liability will increase as $\pi^{\mathrm{e}}$ rises according to the Fisher effect of $r=i-\pi^{\mathrm{e}}$ where $r$ is the real interest rate and $\pi^{\mathrm{e}}$ is the expected interest rate.

In the additional case of the Balassa-Samuelson effect, technological progress leading to labor productivity depends on inter-country difference in the 
relativity of the tradable and non-tradable sectors. The production costs decrease and then the prices of tradable goods decrease as the productivity increases. Therefore, the CPI with the larger weight of tradable decreases but the CPI with the larger weight of non-tradable increases, causing the real exchange rate to fall. The deviation is decomposed as $\frac{(\alpha \mathrm{R}+(1-\alpha) \mathrm{R})-\left(\alpha \mathrm{R}^{*}+(1-\alpha) \mathrm{R}^{*}\right)}{\left(\alpha \mathrm{R}^{*}+(1-\alpha) \mathrm{R}^{*}\right)}$ where $\alpha$ is the tradable share and $(1-a)$ non-tradable share at time $t$.

Current account imbalance can be understood as large current account deficits and surpluses between the Euro members. Let us define the open economy equilibrium condition by using the national income accounting identity as:

$$
\mathrm{Y}-\mathrm{A}=\mathrm{S}-\mathrm{I}=\mathrm{Sp}-\mathrm{I}-(\mathrm{G}-\mathrm{T})=\mathrm{NX}
$$

where $\mathrm{Y}$ is the real GDP, $\mathrm{A}$ is the aggregate domestic spending, $\mathrm{S}$ is the national saving, $\mathrm{I}$ is the investment, NX is the net export, $\mathrm{S}_{\mathrm{p}}$ is the private saving, (G-T) is the negative government saving (government deficit). The equation (1) indicates that government deficits will reduce national savings and crowd out investment. Also, the equation implies that domestic residents borrow the amount of trade deficits to fund excess investment.

In the population aging progress across states and over time, augmented social welfare expenditures have partly increased government spending $(G)$ and taxes (T), and thus have aggravated the burden on the deficit (G-T). Also, declining labor forces have decreased private savings into the economic downturn. In other words, a period of aging advance mostly decreases national savings crowding out investment, and exacerbates the current account.

Accordingly, real exchange rate misalignments between the Euro currency union members would be the consequences of different macroeconomic conditions such as current account balances and development phases. Also, population aging would be responsible for the misalignments as mentioned above. From the principal component analysis for the co-movement dynamics at the aging Euro-zone in the longer-term equilibrium, we claim that the national real effective exchange rate can be expressed as:

$$
\mathrm{Q}=\mathrm{F}(\mathrm{T}, \mathrm{A}, \theta)
$$

where $\mathrm{Q}$ denotes the REER, T is the current account, $\mathrm{A}$ is the working population associated demographic change, $\Theta$ is the stage of development with productivity, and $\mathrm{F}(\cdot)$ is the function notation. Eq. (2) implicitly emphasizes why the REER splits among the members.

The estimate of expression (2) can be used to compute the misalignment of the actual REER. The REER will be determined by current account imbalance, the 
productivity difference and aging shock across countries and over time, all other things being equal. Also, this will represent the influence of the REER misalignment.

\section{TESTING RESULTS}

To estimate Eq. (2), we specify the set of dependent and explanatory variables. We obtained the quarterly OECD data of REER applied by the time varying traded-weights, the share of current account per GDP for the balance of current account, the working population for aging, and the labor productivity index for productivity for the period $1^{\text {st }}$ quarter of 1999 to the $3^{\text {rd }}$ quarter of 2013 from Federal Reserve Economic Data-St. Louis Fed.

All single variables are tested for unit roots and co-integration to check out the long-run equilibrium relations in the fashion of Choi (2010). Most of them are found to be the first difference stationary in the augmented Dickey-Fuller and the Phillips-Parron tests while they are not co-integrated in Engle-Granger test in Appendix 1. Also, the estimation equation cannot be defined in first differences because it is not fitted with data in Appendix 2. Also, no logarithmic transformation is used because of some negative observations of the current account balance.

Moreover, the panel variables of eleven Euro countries are tested for unit roots and co-integration by using yearly data for the same period in Table 1 . The current account balance and working population are found to be the level stationary in the augmented Dickey-Fuller test while the real effective exchange rate and productivity are found to be the first stationary in the Phillips-Parron test. And they are narrowly co-integrated in the $10 \%$ significance level by the Engle-Granger test.

TABle 1. TeSting Results for the PANel Unit RoOts AND COINTEGRATION

\begin{tabular}{cccc}
\hline Variables/Model & Dickey-Fuller Test & $\begin{array}{c}\text { Phillips-Parron Test } \\
\text { (Differenced) }\end{array}$ & Engle-Granger Test \\
\hline REER & $(-2.88 \sim-2.9)$ & $(-2.88)$ & $(-3.87)$ \\
CA & -1.19 & $-13.41^{*}$ & - \\
WP(Aging) & $-12.35^{*}$ & - & - \\
Productivity & $-11.70^{*}$ & - & - \\
Model & 0.25 & $-27.56^{*}$ & $-3.68^{(*)}$ \\
\hline
\end{tabular}

\# REER $=$ real effective exchange rate index $(2010=100), C A=$ ratio of current account balance per GDP, $\mathrm{WP}=$ working population implying aging, and Productivity $=$ labor productivity index. Alternatively, the $1^{\text {st }}$ quarter ones are used in WP and Productivity.

\# The entries represent t-value and test statistic from the testing models including constant where an appropriate leg is determined by Akaike information criterion while $(\cdot)$ indicates the critical value for the t-test from RATS.

\# An asterisk $(*)$ denotes that the null of non-stationary is rejected in the $5 \%$ significance level while the null of no co-integration is rejected in the $10 \%$ significance level. 
For the purposes of the significance estimation, Eq. (2) is expressed as follows:

$$
\mathrm{Q}=\alpha+\beta_{1} \mathrm{~T}+\beta_{2} \mathrm{~A}+\beta_{3} \theta+\varepsilon
$$

where $\mathrm{Q}$ is the REER based manufacturing CPI $(2010=100)$, $\mathrm{T}$ is the ratio of current account to GDP, A means the working population aged 15-64 years for all persons, $\theta$ is the labor productivity index, $\alpha$ is the constant, $\beta$ s are the coefficients, and $\varepsilon$ is the error term. All variables are the level series against the spurious estimation.

To compute the equilibrium values in the manner of Rusek (2012), the relevant form of the expression (3) can be written as:

$$
\mathrm{Q}^{*}=\alpha+\beta *{ }_{1} \mathrm{~T} *+\beta *{ }_{2} \mathrm{~A} *+\beta{ }_{3} \theta *+\varepsilon
$$

where $\beta^{*}$ s are the estimated coefficients from the estimation of Eq. (3) at Table 1 and the superscript $\left(^{*}\right)$ indicates the longer-term equilibrium values of explanatory variables. They are obtained via the Hodrick-Presscot filter. The degrees of misalignnment are calculated by using the deviation formula as utilizing results from Eq. (4).

\section{TABLE 2. INDIVIDUAL ESTIMATES FOR THE EUROZONE}

\begin{tabular}{lcccr}
\hline \multicolumn{1}{c}{ Country } & $\begin{array}{c}\text { Current Account } \\
\text { Balance }\end{array}$ & $\begin{array}{c}\text { Working Population } \\
\text { (Aging) }\end{array}$ & Productivity & Constant \\
\hline France & $0.021(0.05)$ & $0.291(0.09)$ & - & -0.12 \\
Germany & $0.007(0.02)$ & - & $-0.689(0.01)$ & 1.67 \\
Italy & $-0.016(0.00)$ & $-0.247(0.05)$ & $-0.589(0.00)$ & 2.53 \\
Spain & $-0.003(0.00)$ & $0.740(0.00)$ & - & -0.14 \\
Netherlands & $0.003(0.08)$ & - & $0.218(0.09)$ & 0.77 \\
Belgium & $-0.006(0.00)$ & - & $0.301(0.00)$ & 0.69 \\
Luxembourg & $-0.005(0.00)$ & $0.006(0.00)$ & - & 1.0 \\
Finland & $0.002(0.06)$ & - & - & 1.01 \\
Austria & $0.005(0.00)$ & - & - & -0.99 \\
Portugal & $0.004(0.00)$ & $0.445(0.00)$ & $-0.217(0.00)$ & -1.91 \\
Ireland & $-0.010(0.00)$ & $0.103(0.00)$ & - & 0.67 \\
Eurozone & - & $0.241(0.00)$ & - & 0.97 \\
\hline Dependent Variable & $=$ REER & & & \\
\hline
\end{tabular}

\# The numbers in parenthesis are the relevant p-values.

\# The working population is million units.

\# All of them are not seasonally adjusted average data while the current account to GDP is seasonally adjusted.

All coefficients in Table 2 are the estimate of equation (3) by OLS for the $1^{\text {st }}$ quarter of 1999 to the $3^{\text {rd }}$ quarter of 2013. If the exclusion test indicates that a variable is not a part of this fitting model, then such a variable is excluded; as a result, no value is reported. In the estimation, the REERs are significantly related 
to the current account balance in the Euro-zone countries. Demographic effects are measured by the working age population in many nations. Stage of development effects are also captured by the productivity.

Appendix 3 reports the results from different structural break estimates before and after 2009 when crises became severe and baby boomers began to retire in earnest. The current account effects have conversely changed after 2009 in Germany, the Netherlands, and elsewhere, while demographic effects have reversed in France and Luxembourg. Also, stage of development effects have reversed in the Euro-zone.

TABLE 3. PANEL ESTIMATES FOR THE EUROZONE

\begin{tabular}{ccccc}
\hline $\begin{array}{c}\text { Dependent } \\
\text { Variable(REER) }\end{array}$ & $\begin{array}{c}\text { Current Account } \\
\text { Balance }\end{array}$ & $\begin{array}{c}\text { Working Population } \\
\text { (Aging) }\end{array}$ & Productivity & Constant \\
\hline Fixed effect & $-0.003(0.01)$ & $0.268(0.00)$ & $0.246(0.00)$ & $0.00(0.00)$ \\
Random effect $^{*}$ & $-0.004(0.00)$ & $0.129(0.01)$ & $0.300(0.00)$ & $0.49(0.00)$ \\
\hline
\end{tabular}

\# The numbers in parenthesis are the relevant p-values.

\# The working population is million units.

\# The Hausman test $=5.97(\mathrm{p}$-value $=0.11)$ does not reject the null hypothesis of random effects would be consistent and efficient at the 5\% level. In this case, the random effect of GLS estimate is preferred under the null hypothesis while the alternative hypothesis of random effects would be inconsistent (the fixed effect) is not taken.

Table 3 reports that the REER is significantly related to the balance of current account, working population, and productivity in the Euro-zone for the $1^{\text {st }}$ quarter of 1999 to the $3^{\text {rd }}$ quarter of 2013. The current account effect is measured by just0.004 in the Euro area group. The demographic effect is measured as 0.129 . This implies the aging efficacy with the relative increase of the non-working age population. The stage of development effect is also captured as 0.3 .

The individual national REERs and their corresponding equilibrium values are reported in Figure 1. The visual inspection of Figure 1 indicates the dynamics of the divergence between individual actual and desired REERs.

It appears in Figure 1 that the discrepancies of the REER misalignments among member nations tapered off around 2000, 2010, and 2013. The REER misalignments have greatly diminished over time. Interestingly, the misalignments of individual and panel REERs for the Eurozone show a steady converging tendency since 2005. This implies that actual REERs have lately converged on their equilibrium rates. Here, we use the misalignment formula as $\left\{\left(\mathrm{S} / \mathrm{S}^{\mathrm{e}}\right)-1\right\}$ where $\mathrm{S}$ is the REER and $\mathrm{S}^{\mathrm{e}}$ is the equilibrium REER.

Table 4 reports the co-movement effects on the misalignment of the equilibrium REER in the Eurozone for the $1^{\text {st }}$ quarter period of 1999 to the $3^{\text {rd }}$ quarter of 2013. The current account balance, working population and productivity have a minor real influence over the misaligned REER by measuring the 
correlation coefficient such as $0.1,0.6$ and -0.02 respectively. In addition, the current account balance and working population which have positive influences in the first period are changed into negative influences.

FIGURE 1. ACTUAL REERS AND EQUILIBRIUM REERS

a) Actual REER across the Euro Members

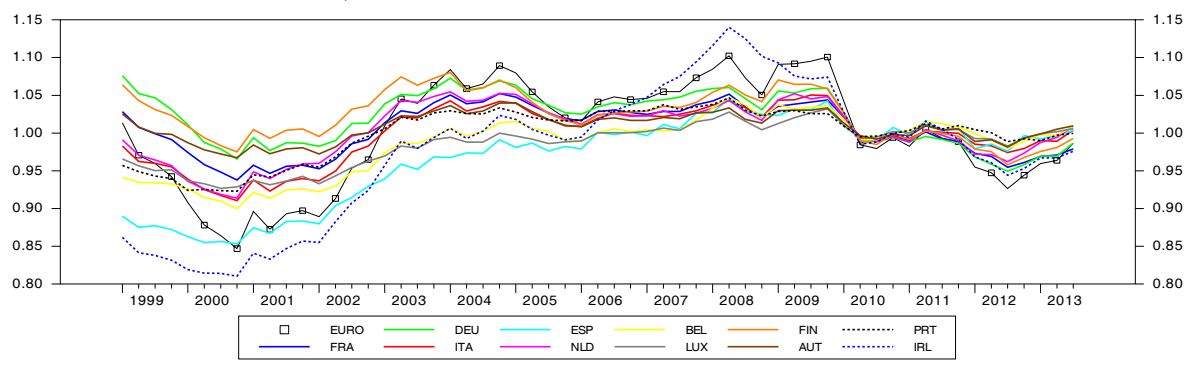

b) Equilibrium REERs across the Euro Countries

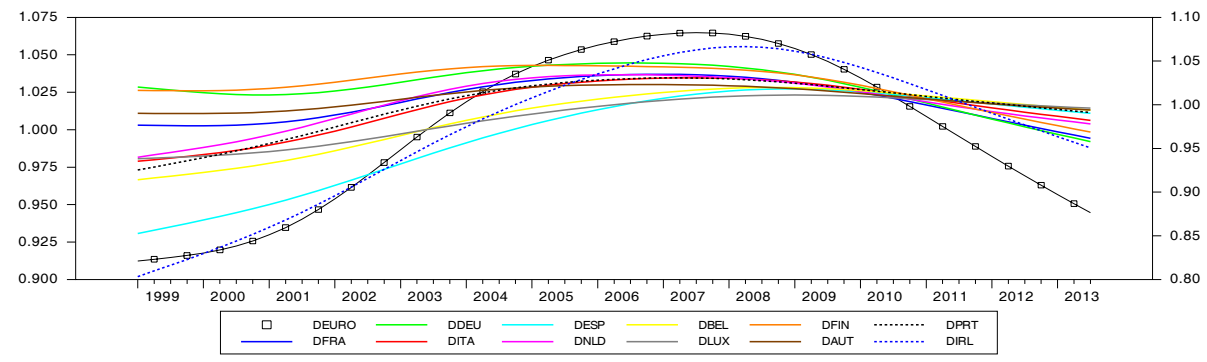

c) Misaligned REERs across the Euro Countries

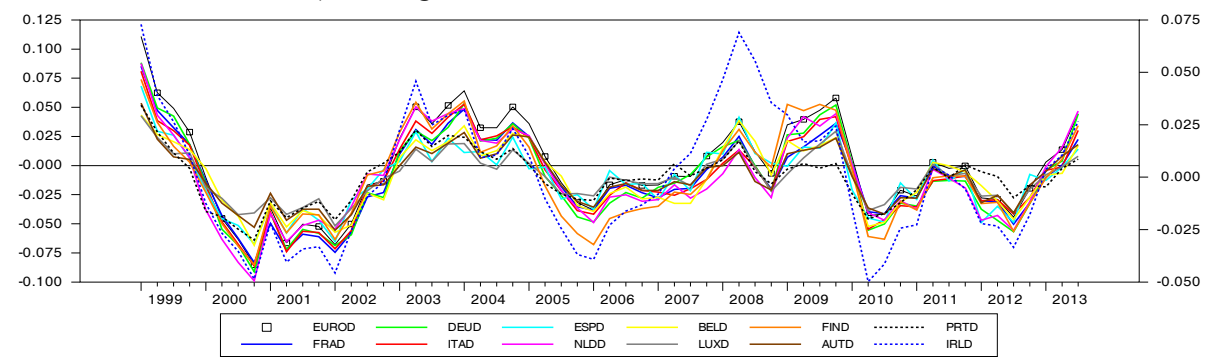

d) Misaligned Panel REER for the Eurozone

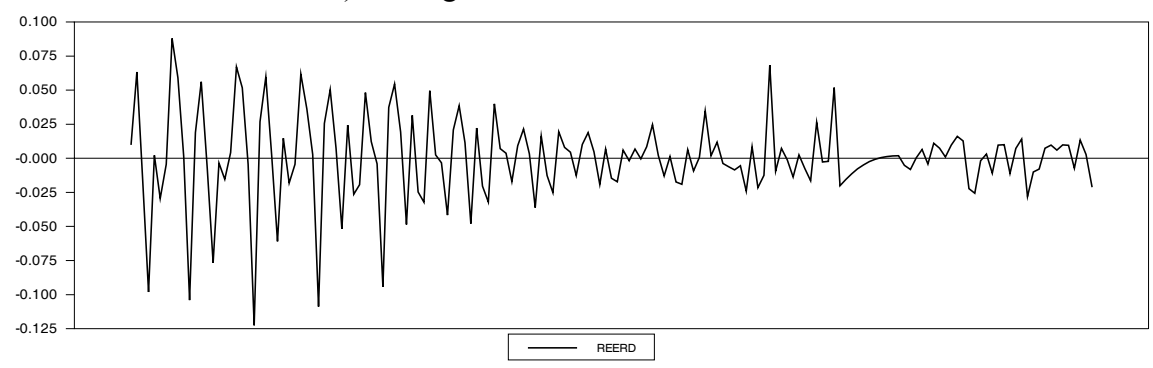


TABle 4. PANel Comovements For the Eurozone

\begin{tabular}{cccc}
\hline $\begin{array}{c}\text { Dependent Variable } \\
\text { (Misaligned REER) }\end{array}$ & $\begin{array}{c}\text { Current Account } \\
\text { Balance }\end{array}$ & $\begin{array}{c}\text { Working Population } \\
\text { (Aging) }\end{array}$ & Productivity \\
\hline Total Period & 0.10 & 0.06 & -0.02 \\
First Period & 0.10 & 0.06 & -0.02 \\
Second Period & -0.09 & -0.09 & -0.22 \\
\hline
\end{tabular}

\# The numbers are the values of coefficient of correlation.

\# Results describe the sequence of two groups (the first period group: 1999-2008 and the second group: 2009-2013).

The results represented in Figure 2 indicate that the REERs become undervalued or overvalued out of their equilibrium REERs over time. The degrees of misalignment of individual REERs relative to the balance of current account are pictured respectively.

Figure 2. REER MisAligNMENTS AND CURRENT ACCOUNT BALANCES FOR EURO AREA

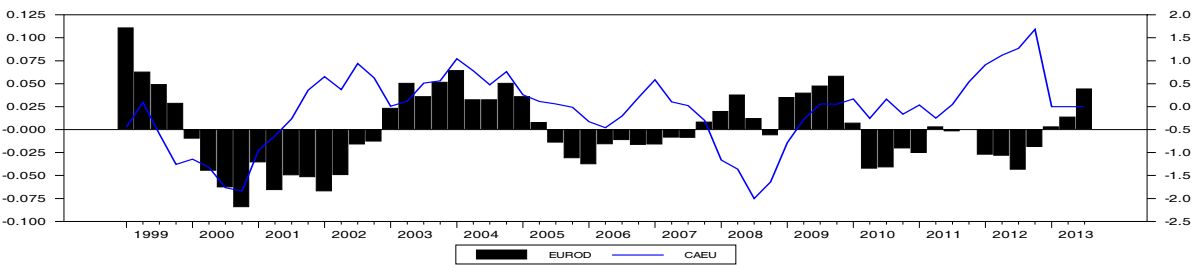

Total Period: $-3.44 /-0.08 \quad 1^{\text {st }}$ Period: $-2.90 /-0.23 \quad 2$ nd Peirod: $-0.21 / 0.23$

\# The first value represents the misaligned REER in \% value (index $=100$ in 2010) each column, while the second indicates the ratio of the current account to GDP in \% value. \# The first period group: 1999-2008, and the second group: 2009-2013.

We calculate the degree of the Euro misalignment, magnitude, persistence, and direction. On average, the Eurozone drives the undervalued rate of $3.44 \%$ out of the equilibrium REER, relative to the current account deficit of $0.08 \%$ for the total sample. The Eurozone indicates a REER misalignment of $-2.90 \%$ with the current account deficit of $0.23 \%$ for the first period, while it has a REER deviation of $-0.21 \%$ with the current account surplus of $0.23 \%$ for the second period. On the other hand, individual member countries represent somewhat different positions in Appendix 4.

\section{CONCLUSIONS}

The equilibrium real exchange rate is an important concept that increases in a currency union. The misalignment of real exchange rates can be the cause of comparative loss, growth slowdown, currency crises, and external imbalances. The divergent dynamics of the real exchange rate in both the actual level and equilibrium stage may exacerbate the current account imbalance in Europe. The balance 
of payments has several channels such as exchange rate process, price adjustment, income adjustment, monetary adjustment mechanism inside the Euro-zone, and exchange rate adjustment mechanisms in the outside world. However, the longer term economic dynamics can vary significantly.

In the longer-term estimation, we find the factors of determination on the REER. The balance of current account, the demographic aging, and the stage of development have a significant value. These effects have conversely changed after 2009 in some member countries. Most REERs have longer term equilibrium relations to the current account balance, working population, and productivity as a Euro-zone group. The current account effect is -0.004 , the stage of development effect is 0.3 , and the demographic effect is 0.129 implying that demographic aging may deepen economic confidence.

Also, we find that individual REER discrepancies have greatly diminished in recent years while the misalignments of individual and group REERs show a steady converging tendency of their equilibrium rates. Also, the co-movement creates effects on the misalignment of the equilibrium REER as a Euro-zone group. This indicates that the current account balance, working population, and productivity have weak influence over the misaligned REER.

Additionally, the Euro-zone drives the undervalued number of $3.44 \%$ with a current account deficit of $0.08 \%$ for the total sample period. This includes a REER misalignment of $-2.90 \%$ with a current account deficit of $0.23 \%$ for the first period and a REER deviation of $-0.21 \%$ with a surplus of $0.23 \%$ for the second period. Individual member countries represent somewhat different positions. This would imply that the REER misalignment does not seem to be closely related to the deficit in the Euro union.

The testing results for the future of the Eurozone would imply that the misalignments of currency cooperation members show an increasingly converging tendency of their equilibrium over time, and they also display co-integration regarding the current account balance and development phase as well as population aging. Moreover, we expect that the agencies overseeing the monetary integration of South and North Korea, if and when it occurs, will learn a salutary lesson from this European experience.

\section{REFERENCES}

Alberola, E. and D. Navia. 2008. Equilibrium Exchange Rates in New EU Members: External Imbalances versus Real Convergence. Review of Development Economics 12(3): 605-619.

Aloy, M. and K. Gente. 2009. The role of demography in the long-run Yen/USD real exchange rate appreciation. Journal of Macroeconomics 31(4): 654-667.

Bayoumi et al. 2006. New Rates from New Weights. IMF staff paper 53(2). 
Berka, M. and M. B. Devereux. 2013. Trends in European Real Exchange Rates. Economic Policy, April: 193-242.

Berka, M., M. B. Devereux, and C. Engel. 2012. Real Exchange Rate Adjustment in and out of the Eurozone. American Economic Review 102(3): 179-185.

Bosworth, B. P. et al. 2004. The Impact of Aging on Financial Market and the Economy: A Survey. Brookings Institute staff paper.

Cavallo, A., B. Neiman, and R. Rigobon. 2012. Product Introductions, Currency Unions, and the Real Exchange Rate. NBER Working Paper 18563.

Choi, M. S. 2010. Currency Risks Hedging for Major and Minor Currencies: Constant Hedging vs. Speculative Hedging. Applied Economics Letters 17(3): 305-311.

Coale, A. J. and E. M. Hoover. 1958. Population Growth and Economic Development in Low-Income Countries, Princeton: Princeton University Press.

Clark, P. B. and MacDonald. 1998. Exchange rates and economic fundamentals: a methodological comparison of BEERs and FEERs. IMF Working Paper.

Coudert, V., C. Couharde, and V. Mignon. 2013. On Currency Misalignments within the Euro Area. Review of International Economics 12(1): 35-48.

Couharde, C. and J. Mazier. 2001. The Equilibrium Exchange Rates of European Currencies and the Transition to Euro. Applied Economics 33: 1795-1801.

Debelle, G. and H. Faruqee. 1996. What Determines the Current Account? A CrossSectional and Panel Approach, IMF WP 58.

Gourinchas and Rey. 2007. International Financial Adjustment. Journal of Political Economy 115(4): 665-703.

Hirsch, F. and I. Higgins. 1970. An Indicator of Effective Exchange Rates. IMF Staff Papers, November: 453-87.

Honohan and Lane. 1999. Divergent Inflation Rates in EMU. Prepared for the 37th Panel Meeting of Economic Policy in Athens.

Klau, M. and S. S. Fung. 2006. The new BIS effective exchange rate indices. BIS Quarterly Review, March: 51-65.

Lane, P. R. and J. C. Shambaugh. 2010. Financial Exchange Rates and International Currency Exposures. American Economic Review 100(1): 518-40.

Lee, R. and A. Mason. 2011. Population Aging and the Generational Economy-A Global Perspective, Edward Elgar Publishing Limited.

MacDonald, R. 2000. Concepts to Calculate Equilibrium Exchange Rates: An Overview. Discussion paper, Series 1, Deutsche Bundesbank.

Maeso-Fernandez et al. 2006. Towards the estimation of equilibrium exchange rates for transition economies: Methodological issues and a panel cointegration perspective. Journal of Comparative Economics 34: 499-517.

Modigliani, Franco. 1970. The Life-Cycle Hypothesis of Savings and Inter-country Differences in Savings Ratios. In W.A. Eltis, ed., Induction, Growth, and Trade, London: Clarendon Press: 197-225. 
Nurkse. 1945. Conditions of International Monetary Equilibrium. Essays in International Finance 4: Princeton University Press.

Ross et al. 2009. Fertility and the Real Exchange Rate. Canadian Journal of Economics 42(2): 496-518.

Rusek, A. 2012. The Eurozone's Equilibrium Real Exchange Rates. Modern Economy 3: 534-41.

Turner, P and J. Van't dack. 1993. Measuring international price and cost competitiveness. BIS Economic Papers 39, Basel, November.

Weil, D. N. 1997. The Economics of Population Aging, Handbook of Population and Family Economics 1B: 966-1014.

Williamson, J. 1994. Estimates of FEERs in Estimating equilibrium exchange rates. Institute for International Economics staff paper. 
APPENDIX 1. TESTING RESUlTS FOR THE UNIT ROOTS AND COINTEGRATION

\begin{tabular}{|c|c|c|c|c|}
\hline & $\begin{array}{c}\text { Dickey-Fuller } \\
\text { Test }\end{array}$ & $\begin{array}{l}\text { Phillips-Parron Test } \\
\text { (Differenced) }\end{array}$ & $\begin{array}{c}\text { Engle-Granger } \\
\text { Test }\end{array}$ & Variables/Tests \\
\hline \multirow{5}{*}{ Eurozone } & $(-3.48) \sim-3.52)$ & $(-3.48)$ & $(-4.80)$ & REER \\
\hline & -1.59 & $-6.13^{* *}$ & -1.67 & $\mathrm{CA}$ \\
\hline & -2.71 & $-6.98^{* *}$ & 1.89 & WP(Aging) \\
\hline & -1.79 & 115.37 & -0.52 & Productivity \\
\hline & -3.46 & $-24.84^{* *}$ & -0.93 & Model \\
\hline \multirow{5}{*}{ France } & $(-3.48 \sim-3.51)$ & $(-3.48 \sim-3.51)$ & $(-4.44 \sim-4.77)$ & REER \\
\hline & -1.26 & $-5.80^{* *}$ & 1.05 & $\mathrm{CA}$ \\
\hline & -3.45 & $-10.24^{* *}$ & 6.33 & WP(Aging) \\
\hline & 2.45 & $-6.88^{* *}$ & -0.19 & Productivity \\
\hline & $-7.65^{*}$ & $-25.15^{* *}$ & -2.13 & Model \\
\hline \multirow{5}{*}{ Germany } & $(-3.48 \sim-3.54)$ & $(-3.48 \sim-3.54)$ & $(-4.85)$ & REER \\
\hline & -1.69 & $-6.19^{* *}$ & 5.23 & $\mathrm{CA}$ \\
\hline & -1.99 & $-8.27^{* *}$ & -2.45 & WP(Aging) \\
\hline & -2.51 & $-10.68^{* *}$ & -2.02 & Productivity \\
\hline & -3.91 & $-9.27^{* *}$ & -1.87 & Model \\
\hline \multirow{5}{*}{ Italy } & $(-3.48)$ & $(-3.48)$ & $(-4.68)$ & REER \\
\hline & -1.57 & $-6.24^{* *}$ & -4.24 & $\mathrm{CA}$ \\
\hline & -1.92 & $-10.39^{* *}$ & $-6.29^{* * *}$ & WP(Aging) \\
\hline & -1.79 & $-7.55^{* *}$ & -2.33 & Productivity \\
\hline & $-4.07^{*}$ & $-21.89^{* *}$ & -3.80 & Model \\
\hline \multirow{5}{*}{ Spain } & $(-3.48)$ & $(-3.48)$ & $(-4.68)$ & REER \\
\hline & -1.42 & $-9.84^{* *}$ & 0.37 & $\mathrm{CA}$ \\
\hline & -0.98 & $-10.81^{* *}$ & 6.37 & WP(Aging) \\
\hline & 0.43 & -2.01 & -0.23 & Productivity \\
\hline & -1.18 & $-66.59^{* *}$ & -2.64 & Model \\
\hline \multirow{5}{*}{ Netherlands } & $(-3.48 \sim-3.49)$ & $(-3.48)$ & $(-4.69)$ & REER \\
\hline & -1.67 & $-6.15^{* *}$ & 0.50 & $\mathrm{CA}$ \\
\hline & -2.47 & $-13.42^{* *}$ & 8.43 & WP(Aging) \\
\hline & -2.12 & $-6.21^{* *}$ & 0.57 & Productivity \\
\hline & -3.35 & $-27.20^{* *}$ & -2.53 & Model \\
\hline \multirow{5}{*}{ Belgium } & $(-3.48)$ & $(-3.48 \sim-3.49)$ & $(-4.68)$ & REER \\
\hline & -1.63 & $-6.24^{* *}$ & -0.01 & $\mathrm{CA}$ \\
\hline & $-5.53^{*}$ & $-7.28^{* *}$ & -1.68 & WP(Aging) \\
\hline & -2.40 & $-7.18^{* *}$ & 1.44 & Productivity \\
\hline & $-3.84^{*}$ & $-19.69^{* *}$ & -2.33 & Model \\
\hline \multirow{5}{*}{ Luxembourg } & $(-3.48 \sim-3.52)$ & $(-3.48)$ & $(-4.77)$ & REER \\
\hline & -1.74 & $-6.81^{* *}$ & 0.07 & $\mathrm{CA}$ \\
\hline & $-7.15^{*}$ & $-17.41^{* *}$ & -4.08 & WP(Aging) \\
\hline & -2.32 & $-9.12^{* *}$ & 0.69 & Productivity \\
\hline & -1.78 & $-16.50^{* *}$ & -3.39 & Model \\
\hline \multirow{5}{*}{ Finland } & $(-3.48)$ & $(-3.48 \sim-3.49)$ & $(-4.68)$ & REER \\
\hline & -2.05 & $-6.08^{* *}$ & -0.52 & $\mathrm{CA}$ \\
\hline & $-6.09^{*}$ & $-8,21^{* *}$ & 2.16 & WP(Aging) \\
\hline & 0.53 & $-7.82^{* *}$ & 1.38 & Productivity \\
\hline & -2.80 & $-15.11^{* *}$ & -2.53 & Model \\
\hline \multirow{5}{*}{ Austria } & $(-3.48)$ & $(-3.48)$ & $(-4.68)$ & REER \\
\hline & -2.04 & $-7.04^{* *}$ & 4.35 & $\mathrm{CA}$ \\
\hline & -2.18 & $-12.11^{* *}$ & 4.59 & WP(Aging) \\
\hline & -2.87 & $-8.35^{* *}$ & -1.07 & Productivity \\
\hline & $-4.70^{*}$ & $-14.38^{* *}$ & -3.85 & Model \\
\hline
\end{tabular}




\begin{tabular}{ccccc}
\hline & $(-3.48)$ & $(-3.48)$ & $(-4.68)$ & REER \\
\multirow{4}{*}{ Portugal } & -0.75 & $-6.71^{* *}$ & 5.90 & CA \\
& -1.31 & $-8.45^{* *}$ & 14.58 & WP(Aging) \\
& 3.56 & $-7.76^{* *}$ & -1.91 & Productivity \\
& $-4.56^{* *}$ & $-35.24^{* *}$ & -3.70 & Model \\
\hline \multirow{3}{*}{ Ireland } & $(-3.48)$ & $(-3.48)$ & $(-4.68)$ & REER \\
& -1.11 & $-5.32^{* *}$ & -2.06 & CA \\
& -0.30 & $-13.13^{* *}$ & 3.75 & WP(Aging) \\
& 1.09 & $-5.49^{* *}$ & 0.77 & Productivity \\
\hline
\end{tabular}

\# We use quarterly data. And quarterly working population is 10 million units.

\# The entries represent t-value and test statistic from the testing models including constant plus linear trend where a proper leg is determined by Akaike information criterion while $(\cdot)$ indicates the critical value for the t-test from RATS.

\# An asterisk $\left({ }^{*},{ }^{* *},{ }^{* * *}\right)$ denotes that the null of non-stationary is rejected, and the null of no cointegration is rejected in the 5\% significance level.

APPENDIX 2. PRELIMINARY TESTING RESUltS FOR THE FitTing MODEL

\begin{tabular}{|c|c|c|c|c|c|}
\hline & $\begin{array}{c}\text { Current Account } \\
\text { Balance }(\mathrm{CA})\end{array}$ & $\begin{array}{c}\text { Working } \\
\text { Population(Aging) }\end{array}$ & Productivity & Constant & Model/Data \\
\hline \multirow{6}{*}{ Eurozone } & $-0.02(.52)$ & $3.03(.21)$ & $0.98(.79)$ & $-0.03(.97)$ & $\begin{array}{c}\text { Yearly Level } \\
\text { Yearly r }\end{array}$ \\
\hline & $0.01(.69)$ & $-4.58(.85)$ & $-1.47(.41)$ & $0.01(.76)$ & $\begin{array}{l}\text { Difference } \\
\text { Quarterly }\end{array}$ \\
\hline & $\mathbf{0 . 0 3}(.02)$ & $8.14(.51)$ & $\mathbf{1 . 5 5}(.00)$ & $-0.51(.29)$ & Level(1) r d \\
\hline & $\mathbf{- 0 . 0 4}(.05)$ & $3.59(.24)$ & $\mathbf{- 1 . 5 3}(.01)$ & $-5.20(.42)$ & Level(2) \\
\hline & $0.01(.44)$ & $-2.54(.49)$ & $-0.06(.73)$ & $0.001(.71)$ & $\begin{array}{l}\text { Quarterly } \\
\text { Differ(1) r } \\
\text { Quarterly }\end{array}$ \\
\hline & $-0.01(.44)$ & $3.09(.93)$ & $0.39(.31)$ & $-0.01(.31)$ & Differ(2) \\
\hline \multirow{6}{*}{ France } & $0.02(.19)$ & $0.12(.18)$ & $3.19(.82)$ & $0.86(.11)$ & YL \\
\hline & $-0.02(.11)$ & 1.87(.06) & $-1.62(.11)$ & $-0.01(.11)$ & YD \\
\hline & $\mathbf{0 . 0 2}(.04) \mathrm{v}$ & $5.76(.01) \mathrm{v}$ & $-0.06(.79)$ & $-1.16(.10)$ & $\mathrm{QL}(1) \mathrm{d}$ \\
\hline & $0.02(.15)$ & $-8.72(.89)$ & $-0.51(.15)$ & $1.88(.46)$ & QL(2) \\
\hline & $-0.01(.25)$ & $-1.35(.10)$ & $0.08(.23)$ & $0.01(.13)$ & $\mathrm{QD}(1) \mathrm{r}$ \\
\hline & $-0.002(.71)$ & 1.09(.09) & $\mathbf{0 . 1 8}(.09)$ & $-0.01(.16)$ & $\mathrm{QD}(2) \mathrm{r}$ \\
\hline \multirow{6}{*}{ Germany } & $0.004(.43)$ & $-0.03(.59)$ & 2.23(.09) & $0.94(.00)$ & YL \\
\hline & $0.01(.52)$ & $-0.02(.73)$ & $9.42(.48)$ & $-0.01(.56)$ & YD r \\
\hline & $\mathbf{0 . 0 1}(.01)$ & $-1.29(.00)$ & $-0.35(.14)$ & $1.41(.00)$ & QL(1) \\
\hline & $-0.01(.35)$ & $-1.41(.72)$ & $-0.86(.03)$ & $2.68(.24)$ & QL(2) \\
\hline & $0.004(.25)$ & $\mathbf{- 5 . 0 4 ( . 0 2 )}$ & $0.05(.69)$ & $-0.002(.34)$ & $\mathrm{QD}(1)$ \\
\hline & $0.001(.81)$ & $1.83(.43)$ & $-0.07(.73)$ & $-0.004(.31)$ & $\mathrm{QD}(2) \mathrm{r}$ \\
\hline \multirow{6}{*}{ Italy } & $-0.01(.29)$ & $-0.76(.19) \mathrm{v}$ & $1.50(.21) \mathrm{v}$ & $0.99(.00)$ & YL \\
\hline & $0.01(.19)$ & $0.29(.59) \mathrm{v}$ & $-4.12(.01) \mathrm{v}$ & $0.01(.34)$ & YD r \\
\hline & $\mathbf{- 0 . 0 2}(.00)$ & $-4.81(.07)$ & $\mathbf{- 0 . 5 3}(.06)$ & $3.36(.00)$ & $\mathrm{QL}(1) \mathrm{d}$ \\
\hline & $-0.004(.16)$ & $-2.25(.00)$ & $0.24(.31)$ & $9.68(.00)$ & $Q L(2) d$ \\
\hline & $0.002(.39)$ & $-1.41(.45)$ & $-0.10(.11)$ & $0.002(.42)$ & $\mathrm{QD}(1) \mathrm{r}$ \\
\hline & $0.01(.33)$ & $1.22(.92)$ & $-0.03(.86)$ & $-0.003(.38)$ & $\mathrm{QD}(2) \mathrm{r}$ \\
\hline \multirow{6}{*}{ Spain } & $0.003(.52)$ & $-2.11(.00) \mathrm{v}$ & $\mathbf{4 . 4 5}(.00) \mathrm{v}$ & $0.99(.00)$ & YL \\
\hline & $0.00(.96)$ & $-0.02(.98) \mathrm{v}$ & $1.39(.94) \mathrm{v}$ & $0.01(.23)$ & YD r \\
\hline & $\mathbf{0 . 0 1}(.01)$ & 1.14(.00) & $-0.08(.45)$ & $-0.59(.00)$ & $\mathrm{QL}(1) \mathrm{d}$ \\
\hline & $0.001(.72)$ & $1.04(.27)$ & $-0.07(.65)$ & $-0.53(.71)$ & $\mathrm{QL}(2) \mathrm{rd}$ \\
\hline & $-0.001(.62)$ & $1.25(.28)$ & $\mathbf{0 . 0 9}(.03)$ & $-0.003(.60)$ & $\mathrm{QD}(1) \mathrm{r}$ \\
\hline & $\mathbf{0 . 0 0 4}(.09)$ & $-1.50(.35)$ & $0.12(.05)$ & $-0.01(.14)$ & $\mathrm{QD}(2)$ \\
\hline
\end{tabular}




\begin{tabular}{|c|c|c|c|c|c|}
\hline \multirow{6}{*}{ Netherlands } & 0.01(.03) & $0.02(.69)$ & $1.12(.34)$ & $0.89(.00)$ & YL \\
\hline & $0.001(.86)$ & $-0.08(.15)$ & $1.89(.11)$ & $0.01(.46)$ & YD r \\
\hline & $\mathbf{0 . 0 1}(.00)$ & $-4.75(.87)$ & $0.20(.14)$ & $0.77(.00)$ & $\mathrm{QL}(1) \mathrm{d}$ \\
\hline & $\mathbf{- 0 . 0 1}(.01)$ & $-2.91(.28)$ & $-0.10(.62)$ & $4.37(.14)$ & $\mathrm{QL}(2) \mathrm{d}$ \\
\hline & $-0.00(.73)$ & $-2.21(.07)$ & $0.002(.96)$ & $0.002(.26)$ & $\mathrm{QD}(1) \mathrm{r}$ \\
\hline & $0.003(.18)$ & $-3.19(.17)$ & $0.09(.22)$ & $-0.003(.40)$ & $\mathrm{QD}(2) \mathrm{rd}$ \\
\hline \multirow{6}{*}{ Belgium } & $-0.01(.26)$ & 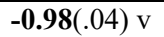 & $\mathbf{1 . 7 5}(.03) \mathrm{v}$ & $0.99(.00)$ & YL \\
\hline & $-0.005(.23)$ & $0.41(.47) \mathrm{v}$ & $-6.19(.52) \mathrm{v}$ & $0.01(.29)$ & YD r \\
\hline & $0.002(.32)$ & $\mathbf{3 . 0 6}(.00)$ & $0.05(.60)$ & $-1.18(.00)$ & $\mathrm{QL}(1) \mathrm{d}$ \\
\hline & $-0.002(.12)$ & $\mathbf{- 3 . 0 2}(.00)$ & $0.04(.63)$ & $3.15(.00)$ & $\mathrm{QL}(2) \mathrm{d}$ \\
\hline & $0.001(.26)$ & 7.74(.59) & $-0.03(.20)$ & $0.002(.47)$ & $\mathrm{QD}(1) \mathrm{r}$ \\
\hline & $-0.001(.68)$ & $-8.54(.87)$ & $0.02(.65)$ & $-0.001(.87)$ & $\mathrm{QD}(2) \mathrm{r}$ \\
\hline \multirow{6}{*}{ Luxembourg } & $\mathbf{- 0 . 0 0 5}(.00)$ & $\mathbf{0 . 0 7}(.00)$ & $2.70(.92)$ & $1.00(.00)$ & YL \\
\hline & $-0.002(.19)$ & $\mathbf{0 . 0 4}(.02)$ & $-4.04(.83)$ & $0.002(.52)$ & YD \\
\hline & $4.14(.96)$ & $8.17(.29)$ & $\mathbf{0 . 2 5}(.05)$ & $0.70(.00)$ & $\mathrm{QL}(1) \mathrm{rd}$ \\
\hline & $-0.001(.14)$ & $-7.55(.01)$ & $0.02(.83)$ & $1.25(.00)$ & $\mathrm{QL}(2)$ \\
\hline & $\mathbf{0 . 0 0}(.05)$ & $-4.45(.06)$ & $\mathbf{0 . 1 0}(.01)$ & $0.001(.25)$ & $\mathrm{QD}(1)$ \\
\hline & $0.00(.51)$ & $-5.21(.42)$ & $0.09(.18)$ & $0.00(.89)$ & $\mathrm{QD}(2) \mathrm{r}$ \\
\hline \multirow{6}{*}{ Finland } & $0.00(.94)$ & $0.005(.98) \mathrm{v}$ & $1.29(.74) \mathrm{v}$ & $0.98(.00)$ & YLr \\
\hline & $-0.005(.36)$ & $0.36(.39) \mathrm{v}$ & $-5.41(.43) \mathrm{v}$ & $-0.001(.95)$ & YD r \\
\hline & $\mathbf{- 0 . 0 1}(.01)$ & $-1.47(.68)$ & $0.03(.81)$ & $1.55(.19)$ & $\mathrm{QL}(1) \mathrm{rd}$ \\
\hline & $0.005(.21)$ & $6.60(.18)$ & $\mathbf{- 0 . 3 7}(.08)$ & $-0.95(.58)$ & $\mathrm{QL}(2) \mathrm{d}$ \\
\hline & $0.00(.83)$ & $-9.41(.05)$ & $0.03(.48)$ & $0.001(.53)$ & $\mathrm{QD}(1) \mathrm{r}$ \\
\hline & $-5.21(.96)$ & $\mathbf{- 2 . 0 5}(.00)$ & $\mathbf{0 . 1 1}(.07)$ & $-0.01(.01)$ & $\mathrm{QD}(2)$ \\
\hline \multirow{6}{*}{ Austria } & $0.005(.27)$ & $0.02(.93) \mathrm{v}$ & $-2.45(-.95) \mathrm{v}$ & $0.99(.00)$ & YL r \\
\hline & $-0.001(.89)$ & $0.61(.22) \mathrm{v}$ & $-9.27(.24) \mathrm{v}$ & $0.01(.34)$ & YD r \\
\hline & $0.003(.29)$ & $\mathbf{2 . 6 3}(.00)$ & $\mathbf{- 0 . 3 5}(.02)$ & $-0.09(.71)$ & $\mathrm{QL}(1) \mathrm{d}$ \\
\hline & $-0.002(.65)$ & $\mathbf{- 3 . 3 2}(.01)$ & $-0.02(.88)$ & $2.90(.00)$ & $\mathrm{QL}(2) \mathrm{d}$ \\
\hline & $0.00(.88)$ & $9.93(.22)$ & $-0.02(.79)$ & $-0.001(.60)$ & $\mathrm{QD}(1) \mathrm{r}$ \\
\hline & $0.00(.88)$ & $9.93(.22)$ & $-0.02(.79)$ & $-0.001(.60)$ & $\mathrm{QD}(2) \mathrm{r}$ \\
\hline \multirow{6}{*}{ Portugal } & $-0.002(.73)$ & $-0.03(.73)$ & $3.59(.91)$ & $0.99(.00)$ & YLrd \\
\hline & $0.004(.22)$ & $0.05(.19)$ & $5.92(.63)$ & $0.004(.45)$ & YD r \\
\hline & $\mathbf{0 . 0 0 5}(.00)$ & 4.53(.00) & $-0.11(.22)$ & $-2.04(.00)$ & $\mathrm{QL}(1) \mathrm{d}$ \\
\hline & $0.001(.61)$ & $1.48(.12)$ & $\mathbf{- 0 . 1 6}(.10)$ & $0.12(.86)$ & QL(2) \\
\hline & $0.002(.20)$ & $1.26(.55)$ & $0.003(.94)$ & $0.001(.65)$ & $\mathrm{QD}(1) \mathrm{r}$ \\
\hline & $0.00(.92)$ & $7.09(.65)$ & $0.04(.52)$ & $-0.001(.67)$ & $\mathrm{QD}(2) \mathrm{r}$ \\
\hline \multirow{6}{*}{ Ireland } & $\mathbf{- 0 . 0 2}(.10)$ & $0.16(.31)$ & $-5.39(.17)$ & $1.07(.00)$ & YLrd \\
\hline & $-0.01(.12)$ & $-0.09(.18)$ & $2.26(.18)$ & $0.02(.11)$ & YD \\
\hline & $\mathbf{- 0 . 0 2}(.00)$ & $-1.87(.48)$ & $1.19(.00)$ & $-0.12(.56)$ & $\mathrm{QL}(1) \mathrm{d}$ \\
\hline & $-0.01(.21)$ & $3.08(.59)$ & $\mathbf{- 0 . 5 2}(.05)$ & $0.60(.75)$ & QL(2) \\
\hline & $0.00(.91)$ & $\mathbf{- 1 . 1 2 ( . 0 9 )}$ & $0.002(.98)$ & $0.01(.01)$ & $\mathrm{QD}(1) \mathrm{r}$ \\
\hline & $0.003(.32)$ & $-1.05(.94)$ & $-0.25(.36)$ & $-0.01(.31)$ & $\mathrm{QD}(2) \mathrm{r}$ \\
\hline
\end{tabular}

\# The dependent variable is REER.

\# We use both yearly and quarterly data. The quarterly data are divided into two groups (group 1: 1999-2008 and group 2: 2009-2013). And yearly productivity is 10,000 units while quarterly working population is 10 million units.

\# $(\cdot)$ indicates the p-value from SPSS.

\# All the models have no multicollinearity with appropriate VIF except v-marked ones. And all the models are significant with appropriate $\mathrm{R}^{2}$ except r-marked ones. And all the models are independently auto-correlated with appropriate $\mathrm{D}-\mathrm{W}$ except d-marked ones. 
APPENDIX 3. INDIVIDUAL Estimates FOR THE STRUCTURAL CHANGE

\begin{tabular}{cccc}
\hline Country & Current Account Balance & $\begin{array}{c}\text { Working Population } \\
\text { (Aging) }\end{array}$ & Productivity \\
\hline France & $0.023(.03) / 0.025(.05)$ & $5.571(.00) /-4.107(.52)$ & - \\
Germany & $0.010(.00) /-0.010(.26)$ & - & $-0.527(.04) /-0.820(.02)$ \\
Italy & $-0.027(.00) /-0.004(.16)$ & $-4.807(.07) /-2.253(.00)$ & $-0.526(.06) / 0.235(.31)$ \\
Spain & $0.005(.02) / 0.00(.89)$ & $1.108(.00) / 9.905(.28)$ & - \\
Netherlands & $0.009(.00) /-0.008(.00)$ & - & $0.197(.12) /-0.127(.53)$ \\
Belgium & $-0.006(.02) / 0.00(.89)$ & - & $0.390(.00) /-0.067(.55)$ \\
Luxembourg & $0.001(.54) /-0.001(.13)$ & $1.275(.11) /-7.80(.00)$ & - \\
Finland & $-0.006(.00) / 0.008(.034)$ & - & - \\
Austria & $0.005(.00) / 0.004(.32)$ & - & - \\
Portugal & $0.005(.00) / 0.001(.61)$ & $4.527(.00) / 1.482(.12)$ & $-0.109(.22) /-0.157(.10)$ \\
Ireland & $-0.025(.00) /-0.006(.22)$ & $3.496(.24) / 7.184(.24)$ & - \\
Eurozone & - & $\mathbf{3 . 1 0 1}(.00) / \mathbf{1 . 1 2 3}(.80)$ & $1.758(.00) /-1.972(.00)$ \\
\hline Dependent Variable $=$ REER & &
\end{tabular}

\# The numbers in parenthesis are the p-values.

\# Results describe the sequence of two groups (the first group: 1999-2008 and the second group: 2009-2013).

APPENDiX 4. REER MisALIGNMENTS AND CURRENT ACCOUnT BALANCES

a) France

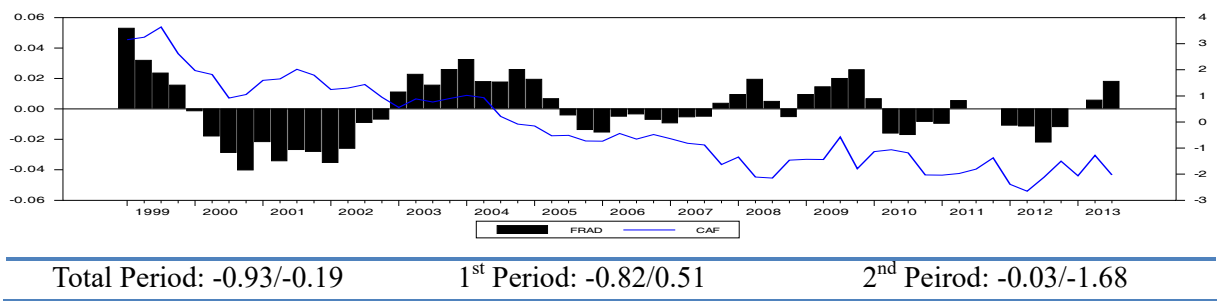

b) Germany

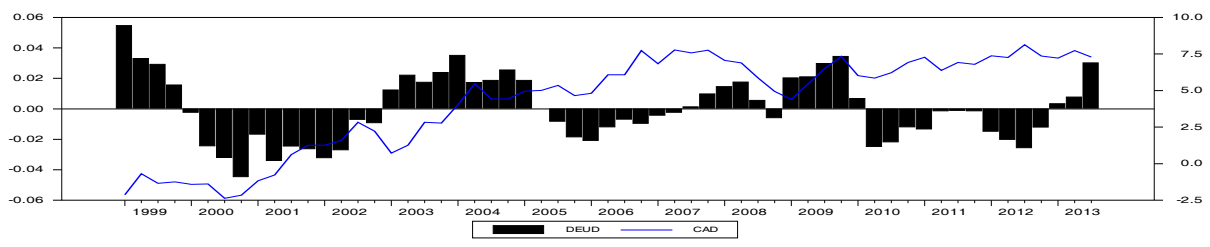

Total Period: $-0.98 / 4.22 \quad 1^{\text {st }}$ Period: $-0.78 / 3.01 \quad 2^{\text {nd }}$ Peirod: $-0.11 / 6.76$

c) Italy

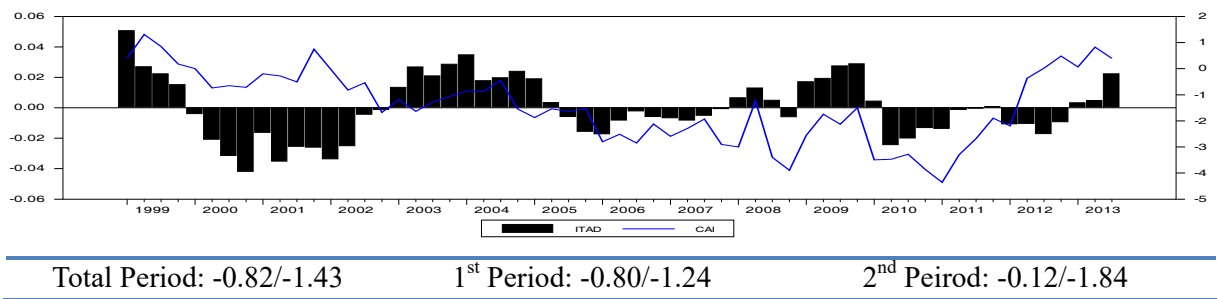


d) Spain

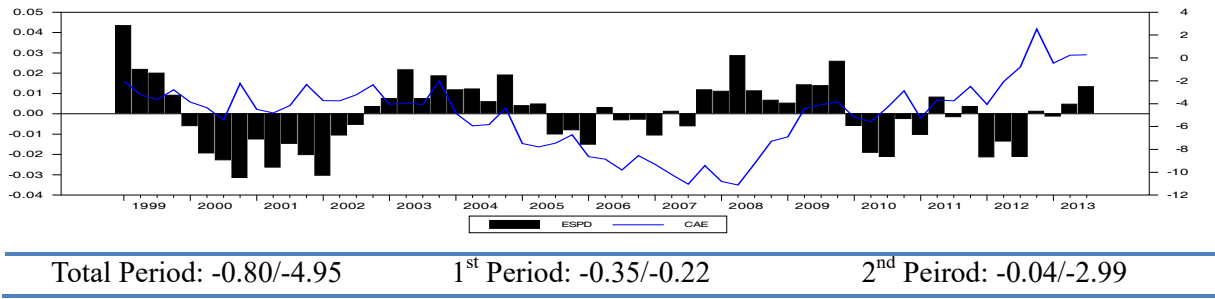

e) Netherlands

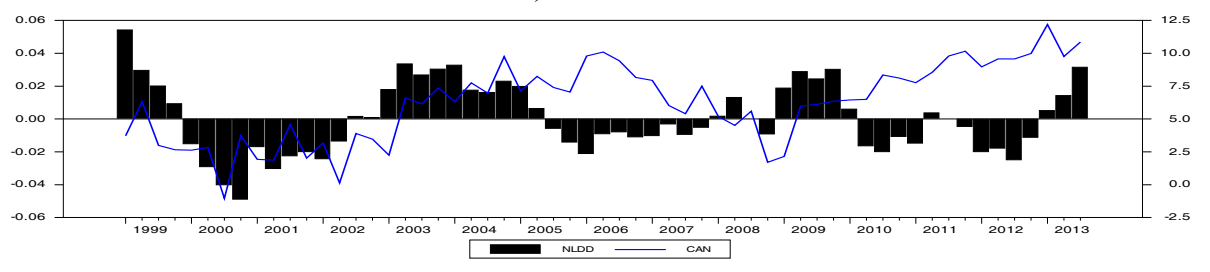

f) Belgium

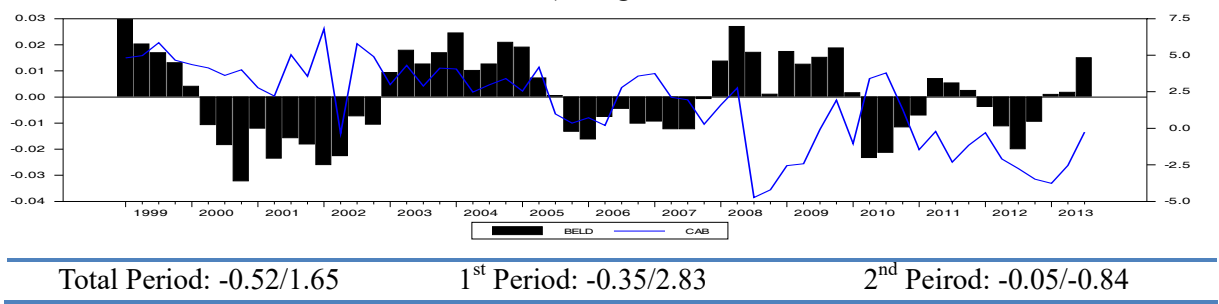

g) Luxembourg

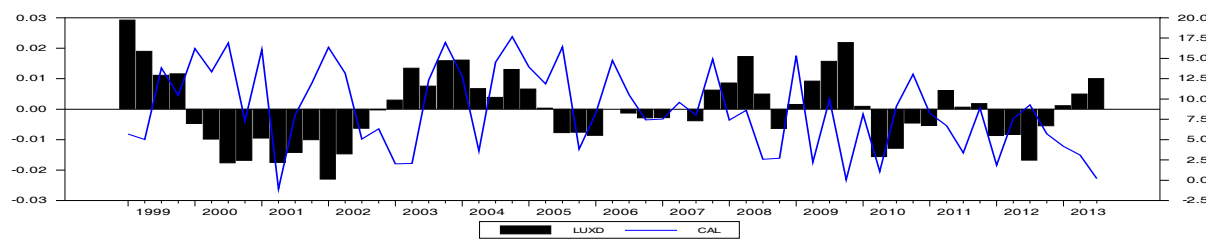

h) Finland

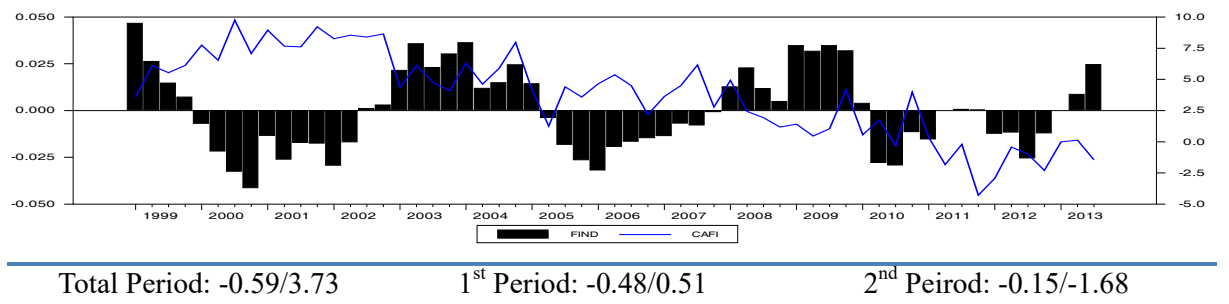


i) Austria

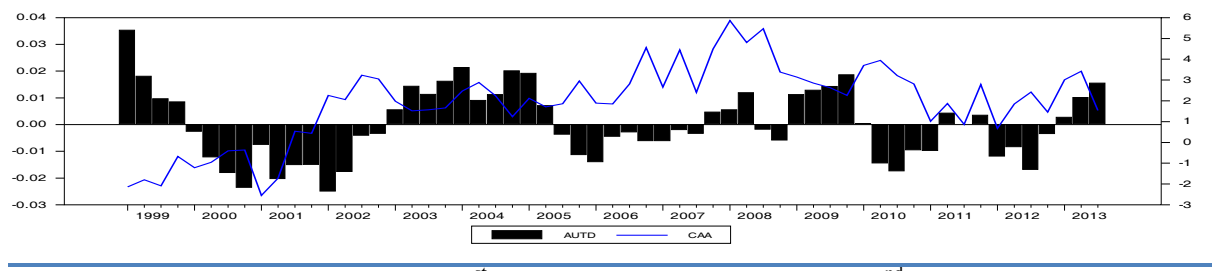

Total Period: $-0.29 / 1.89$

$1^{\text {st }}$ Period: $-0.31 / 1.66$

$2^{\text {nd }}$ Peirod: $-0.07 / 2.39$

j) Portugal

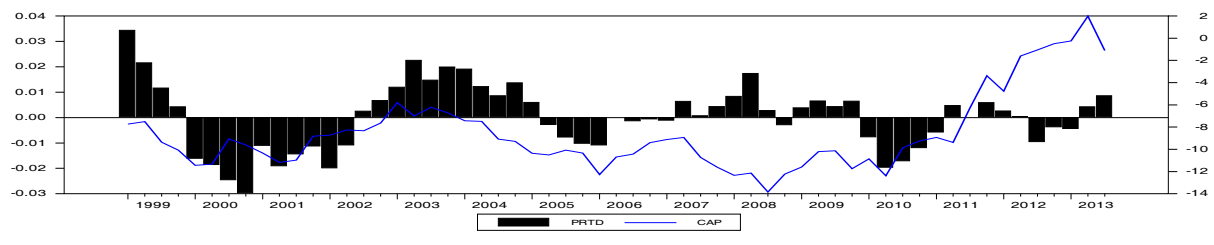

Total Period: $-0.52 /-8.56$

$1^{\text {st }}$ Period: -0.44/-9.61

$2^{\text {nd }}$ Peirod: $-0.02 /-6.38$

k) Ireland

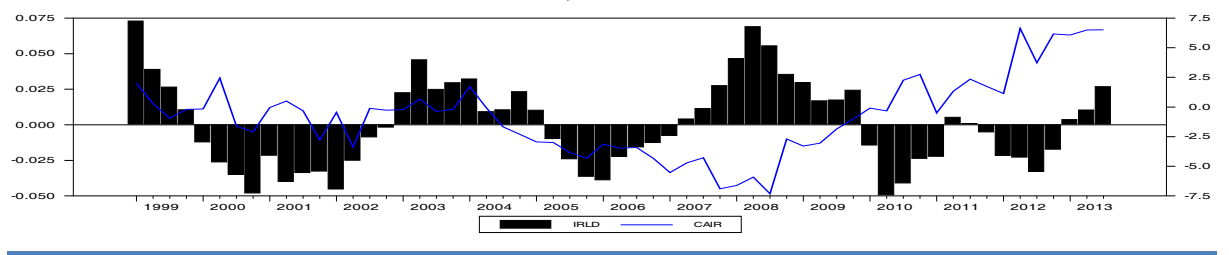

Total Period: $-3.19 /-0.76$

$1^{\text {st }}$ Period: $-0.61 /-1.24$

$2^{\text {nd }}$ Peirod: $-0.08 /-1.84$ 